\title{
"Bring the Boys Back Home!" The Forgotten Fight for Restricting Outward Migration When/Where it is still Possible. The Case of Greece
}

\author{
Periklis Polyzoidis \\ Associate Professor \\ Department of Social Policy \\ Democritus University of Thrace \\ 4, Polyfimou street \\ 69132 Komotini/Greece \\ Giorgos Tsertekidis \\ Researcher \\ Department of Social Policy \\ Democritus University of Thrace \\ 1, Panagi Tsaldari Street \\ 69132 Komotini/Greece
}

\begin{abstract}
We focus on Greece as an example of a country that stands between the very poor countries that are doomed to send migrants and the rich countries that are doomed to receive them. We note the importance of stopping outward migration from countries such as Greece, which are democratic, well organized and not poor. On the one hand, we try to investigate the reasons why modern Greeks migrate, and on the other hand, we try to find measures that may persuade some Greek migrants to return home. After briefly describing basic elements of the Greek diaspora, we focus on the current situation based on a questionnaire sent to all official Greek representations all over the world and numerous local associations of Greeks in countries with a large Greek population. We acquire more detailed information by in-depth interviews with highly ranked officials of the Greek Foreign Ministry and Greek migrants.
\end{abstract}

Keywords: Greece, outward migration, repatriation motives

\section{Greeks under pressure}

The pressure of enormous forced migration waves due to climate change (drought, flood, fire), natural disasters, diseases, wars and conflicts can have unprecedent negative outcomes for the world as we know it. It is obviously not possible for the entire world population (7.71 billion) (World Population Clock, 2019) to achieve a comfortable life in the $25 \%$ of the world's territory (or even less in the megacities) that cover the most developed and safe regions and comprise the main target of contemporary migration. The rise of nationalism in the Western world is mainly based on the fear of uncontrolled migration towards the core countries. As long as the Western world cannot find appropriate solutions, the pressure of the growing overpopulation will lead to unprecedent turbulence. There is much literature that covers various aspects of these phenomena. However, why should a paper concerning Greece be interesting for an international audience? The answer is that Greece is a country that is not so rich that it could represent the desired destination for migrants from the most challenging regions of the planet, but at the same time, it is not so poor that migrating would be the only solution for its inhabitants. Maintaining the native populations in countries such as Greece, where living conditions are still affordable should be a target within the spectrum of strategies for mitigating international migration.

Greeks often grumble that "we live in a tiny helpless country", but this is not true. Compared to all other countries, Greece holds the 50th position by GDP (219,097 billion USD) and by purchasing power parity (29,123 USD), (World Economic Outlook Database, 2019), the $84^{\text {th }}$ by population $(10,741,165)$, the $96^{\text {th }}$ by territory $\left(131,940 \mathrm{~km}^{2}\right)$, and the $118^{\text {th }}$ by population density $\left(131,957\right.$ people $\left./ \mathrm{km}^{2}\right)$, (UN, 2017). Greece is considered the cradle of Western civilization, being the birthplace of democracy, political science, major scientific and mathematical principles, Western philosophy, literature and drama, historiography and the Olympic Games. The sovereign state of Greece is a unitary parliamentary republic and a developed country with an advanced high-income economy, a high quality of life, and a high standard of living. It is a founding member of the United Nations, it was the tenth member to join the European Union and it is part of the Eurozone. 
It is also a member of numerous international institutions, including the Council of Europe, the North Atlantic Treaty Organization (NATO), the Organisation for Economic Co-operation and Development (OECD), and the World Trade Organization (WTO). Greece has a modern infrastructure complete with industrial zones, airports, railways, ports, paved roads and highways and communication, electrical power and natural gas supply networks. The total production of all electric energy producing facilities is 52 billion $\mathrm{kWh}$ or $91 \%$ of the country's own usage. The Greek national health system provides healthcare benefits/services through a network of public/state providers and contracted private providers of primary, hospital and ambulatory care.

Nonetheless, Greece was not prepared to face the financial crisis that hit the world in 2009. The country experienced one of the largest falls in real wages across OECD countries, more than 5\% on average, since the first quarter of 2009. (OECD, 2015). In the spring of 2010, Greece was the first country in the euro area to require financial support to meet its government's payment obligations. The bailout rescue packages (memorandum of understanding) designed by the European Commission, the European Central Bank and the International Monetary Fund (IMF) were linked to the implementation of macroeconomic adjustment programmes that aimed to address the problems that had made countries vulnerable to changes in market confidence (Kougias, 2018). As a direct consequence, private consumption has dropped by a third since 2010, while household income dropped approximately 30\% between 2007 and 2014 (European Union, 2016).

The labor market collapsed. Unemployment reached 25.2\% in June 2016, and it continues to remain the highest within the European Union. Youth unemployment is even worse. The youth unemployment rate in Greece averaged $35.56 \%$ from 1998 until 2019, reaching an all-time high of 60.20\% in February 2013. Currently, it is 40.40 (March 2019). The unemployment rate in Greece averaged 16.24\% from 1998 until 2019, reaching an all-time high of 27.80\% in July 2013 (Trading Economics, 2019). In parallel, the crisis has exerted dangerous downward pressure on labor and social rights (Petmesidou and Guillén, 2015). The welfare state also collapsed. Pensioners are hit hardest by the crisis, as pensions have been slashed by as much as $60 \%$ to an average of 830 Euros a month, while at the same time, prices have been rising (European Union, 2016). In addition, health indices show that the health of the population is getting worse, while the health system faces great challenges (Petmesidou and all, 2015; Economou et al, 2015), and criminality is changing from bad to worse (Tsouvelaset al, 2018).

In 2014, more than one-third of the population was at risk of poverty or social exclusion. The \%age of people at risk of income poverty was approximately $22 \%$, and the number of those severely deprived materially was another $22 \%$ (Eurostat, 2015). Greece is the country with the lowest life satisfaction rating out of all OECD nations (OECD, 2015). In 2016, the most common feelings to be reported were anger (34\%) and disappointment (38\%) (Thegreekzcom.com, 2006). In 2015, half of all Greeks reported that they believe that things are only going to get worse. Furthermore, approximately 60\% appear pessimistic about the country's economic future (Kappa research, 2015). Two-thirds of Greeks stressed that their situation has worsened in terms of their personal finances and family structure, while approximately $70 \%$ think that the situation in Greece took a turn for the worse.

\section{The Greek diaspora and the recurring outward migration waves}

The intolerable situation forced many Greeks to migrate. This is not the first Greek migration in history. The Greek diaspora or "Omogenia" (meaning "common line") is one of the oldest and largest in the world, with a presence from Homeric times to the present. Greeks are constantly leaving Greece; in the last 100 years, there have been three strong migration waves (Korma, 2004).

The first occurred after the first World War, as a result of the War of 1919-1922 that was fought between Greece and the Turkish National Movement during the partitioning of the Ottoman Empire. When the eastern front collapsed, the Greek government accepted the demands of the Turkish national movement and returned to its prewar borders, thus leaving East Thrace and Western Anatolia to Turkey. The original plan was to exchange the Turkish population in Greece for the Greek population in Asia Minor, but the Turks wanted to get rid of allGreek speakers. As a result, rather than following this exchange, millions of Greeks in Asia Minor were killed as they were trying to escape to the motherland. The Turks killed 440,000 Armenian civilians and 264,000 Greek civilians during the war and 3,500,000 to over 4,300,000 Armenians, Greeks, and Assyrians between 1900 and 1923 (Rummel, 1997). Those who managed to escape either became refugees in Greece or moved on to other countries.

Despite the size of the tragedy, the settlement of the 1.2 million survivors had many positive effects on mainland Greece. The population of Greece rose by approximately $1 / 3$ in just a few months, and numerous suburbs, towns and villages were established, most of them named after the region of origin, with the prefix "new" (such as" New Smyrna" or "New Marmaras"). The Greek state, which is not known for its organizational abilities, managed to take measures that proved successful. 
The division of arable land to allow refugees and their descendants to be owners of their own land, resulted in the rise of agricultural production by $400 \%$. The income tax also quadrupled within the next four years, mainly thanks to the newcomers. The growth of trading pushed the Greek economy into a new level of development and industrialization. In a very short time, the skilled refugee population established new industries. At the same time, the homogeneity of the population increased, and new liberal ideas arrived with the refugees from cosmopolitan cities, such as Constantinople and Smyrna. The opposite of these positive effects occurred in Greece after the second and the third migration waves.

The second wave of outward migration occurred after World War II, when Greece was devastated both physically and economically and Greeks migrated massively to escape the economic and political hardships. More than one million Greeks migrated to Australia, Belgium, Canada, France, Germany and the U.S. Between 1955 and 1973, Germany absorbed 603,300 Greek migrants, Australia 170,700, the U.S. 124,000, and Canada 80,200. In total, 61\% of the postwar emigrants resorted to northwestern European countries (Mousourou, 1991). The majority of these emigrants that supplied both the national and international labor markets came from rural areas, where survival was very difficult (Kassimis and Kassimi, 2004).

The third wave is the contemporary wave, which results from the crisis described in the previous section. Lambrianidis (2014) records 222,457 Greek citizens who migrated from 2010 until early 2015, but he estimates that the total emigration outflow of Greeks from 2010 until the end of 2015 ranges between 280,000 and 350,000 people. Half of the immigrants who emigrated after 2010 were unemployed in Greece directly before their emigration. Although lack of jobs seems to be a major reason driving people out of the country, qualitative data clearly show that it is not the only determining reason (Lambrianidis, 2014). The most significant change is in the profile of emigrants. While forty years ago it was mostly the people with lower educational backgrounds who emigrated, the vast majority of the current emigrants are university graduates. During the period of the crisis, $75 \%$ of the emigrants held university degrees. Excluding the graduate emigrants that left together with their families, the number of graduates who are currently abroad is more than 170,000 people. Students and skilled workers also consider that they have no future opportunities in Greece (Labrianidis and Pratsinakis, 2016). The departure of such persons triggers the brain-drain phenomenon (The odoropouloset al, 2014). Deprived of talented people who have the material and intellectual means to help improve the country's economic and political situation, Greece is trapped in a downward spiral (Kapur, 2014).

Shaped by the history of the Greek nation, contemporary Greek "Omogeneia" is divided into two categories: Greeks who live in traditional Greek homelands, such as Albania, Armenia, Corsica, Cyprus, Egypt, Georgia, Italy, North Macedonia, Southern Russia, Turkey and Ukraine, and Greeks who migrated to other countries all over the world. Today, there are Greek communities in 108 countries, the largest being (according to estimations) in the U.S. $(3,000,000)$, Albania $(200,000$ to 550,000), Australia $(420,000)$, UK $(400,000)$, Germany $(370,000)$, Canada $(280,000)$, Chile (100,000), and South Africa (100,000). These are large numbers for a country with 10,124,000 Greeks $(91 \%$ of the total population). Melbourne, Australia, has the largest Greek population of any city in the world outside of Greece $(151,785)$, making it the fifth largest Greek city in the world following Athens $(665,000)$, Thessaloniki $(788,000)$, Patras $(214,000)$ and Heraklion (174,000).

\section{Joining the Dead Nations Society}

While Greeks migrate from Greece, asylum seekers and migrants flood the country. In 2014, Greecefaced a significant increase in arrivals of illegal immigrants and asylum seekers. There are three primary groups with different motivations and origins. The first is made of people leaving for economic reasons, that is, mainly people from sub-Saharan Africa and the Balkans. The second group consists of people seeking protection and who are recognized by European authorities as refugees, such as Syrians and Eritreans. Finally, the third group is made of people fearing insecurity and violence but who are not necessarily qualified as refugees, such as Somalis and some Syrians (Banulescu-Bodgan and Fratzke, 2005).

In 2015, Greece experienced unprecedented arrivals of refugees and migrants mainly from the Middle East, Africa and Asia. The total number of refugees and immigrants arriving in Greece was then 160,000 (UNCHR, 2015). However, the country was largely a transit country in the route of the Balkans to reach Western Europe (Triandafyllidou and Mantanika, 2016). The European Commission estimates that more than 850,000 persons transited through the country in 2015, and 63,000 of them are stranded in Greece (European Commission, 2016). The 2011 national censusdata registered 713,000 third-country nationals and 199,000 EU citizens (non-Greek) living in Greece, accounting for 6.5\% and $1.8 \%$ of the total resident population, respectively. The largest immigrant groups were Albanians $(364,132)$, Bulgarians (31,569), Romanians (23,208), Pakistanis $(15,347)$, Georgians $(13,915)$, and Ukrainians $(11,059)$, followed by Russians $(11,010)$ and finally Poles $(8,384)$. 
In Athens, a growing Muslim community exists, consisting mainly of immigrants from South Asia and the Middle East (mainly of Pakistani, Afghani, and Bangladeshi origin), who began arriving in Greece in the last quarter of the twentieth century. According to estimations, as there are no official records, their number is approximately 380,000 (Pew Research Center, 2017). Working under greatpressure, Greek migration policy changed from an enforcement and deportation philosophy to a philosophy of confinement into camps in which the living conditions are frightening, while even basic health services are limited, and fights, attacks, rapes, blackmails and prostitution are very common (Kingsley, 2016).

Considering these numbers, it is not wise to believe that everything is under control and nothing will happen. The question is whether it is still possible to turn the tide. Southeastern Europe is a very unstable region, and the borders have been reshaped so often that the possibility that there will be no future changes tends to zero. Furthermore, human history is full of examples of great nations, states and empires that simply disappeared. Common factors that may contribute to societal collapse are economic, environmental, social and cultural.

The Tang Dynasty ended as a result of the increased power among the eunuchs, battles with separatists, and finally, peasant revolts. The populace of the Mayan Empire suddenly deposed its kings, abandoned the cities and ceased technological innovation, most likely due to a major drought. The population of the Indus Valley civilization abandoned the cities and purportedly migrated to the southeast. The classical Greek civilization was established by the Greek-speaking Dorians who invaded Greece from the North in approximately 1100 B.C. and drove away the Mycenaean civilization. The Persian Empire was weakened by warfare and internal economic strife when Alexander the Great established his own empire in its lands. His successors proved inadequate in safeguarding his legacy, which was extended from as far west as Greece to as far east as modern-day India. Greece eventually fell into decline and was conquered by the Romans, the new and rising world power.

Two of the many factors that contributed to the fall of the Roman Empire were the rise of a new religion, Christianity, on the one hand, and the arrival of the Huns and the migration of the Barbarian tribes, on the other. By the end of the 14th century, the Byzantine Empire was little more than a dependency of the Ottoman Turks, who finally conquered Constantinople. The fall of the Ottoman Empire was a result of a variety of factors, including foreign invasion, reform and modernization. The Spanish Empire slid into collapse when it declared bankruptcy. The military, fighting on many fronts, went unpaid, military aspirations collapsed and trade slipped to other countries. In 1991, the Soviet Union was the largest country in the world, covering 22.4 million square $\mathrm{km}$, nearly one-sixth of Earth's land surface. Its population numbered more than 290 million, and 100 distinct nationalities lived within its borders. Within a year, the mighty Soviet Union had ceased to exist. The International Linguistics Community (2019) provides a list of 573 extinct languages.By2100, almost half of the languages known today will be lost forever (Wilford, 2007).

\section{Empirical evidence worth less than a donkey's shadow}

Many scholars conclude that it is perfunctory to be certain that tomorrow will be like today. However, in regard to the proposal of policy measures to prevent or at least delay the collapse, there seems to be a complete lack of inspiration. The aim of our empirical approach was to investigate whether there are measures or conditions that could persuade Greeks who live abroad to return to Greece. The study is based on both qualitative and quantitative data.

For the collection of the latter, we sent the link of an online questionnaire to all 421 official Greek representatives all over the world and to 50 local associations of Greeks in foreign cities with a large Greek population, with the plea for distribution. The link was in a 10 raw cover letter email that contained information (with links) about the researchers, the research institute and the aim of the study and provided extra links for issues regarding anonymity, data security and direct contact. The rate of response was very disappointing, with only 187 total visits, 170 of them unique, and 141 responses, although the average time to complete was less than four minutes. This was the first indication that the majority were not concerned about the issue. On the other hand, it is very interesting that approximately half of the respondents added much text when they were given the option to freely express their opinion about the subject. The majority of respondents (42\%) were between their first and fifth years outside Greece, followed by $25 \%$ between the 6 th and the 10th and $20 \%$ between the 11 th and the 30th. Another $10 \%$ left 30 or more years ago, while $5 \%$ were born to Greek parents in countries outside Greece.

Half of the respondents state that the possibility of return is small and 33\% that it is moderate. Only $13 \%$ believe that they will certainly return to Greece, while another $12 \%$ state that there is no possibility for them to return. The remaining $16 \%$ have not yet decided. In the next seven questions, we asked Greek migrants whether they believe that specific measures could motivate some Greek members of their communities to return home. According to their opinion, the most effective measures are the possibility to find a job (91,5\% effective, 3,5\% ineffective), limitations of the Greek bureaucracy $(89,9-9,2)$, and lifetime income tax exemption $(66,7-14,2)$. 
Less effective measures are considered the possibility of avoiding military service $(45,4-23,4)$, free access to university studies $(41,1-16,3)$, tax-free capital transfer $(43,3-13,5)$ and the provision of housing $(52,5$ - 17) (table 1).

Table 1: Measure effectiveness

\begin{tabular}{|l|c|c|c|}
\hline Measure proposal & effective & ineffective & difference \\
\hline Possibility to find a job & 91,5 & 3,5 & 88 \\
\hline Simplification of the Greek bureaucracy & 80,9 & 9,2 & 71,7 \\
\hline Lifetime income tax exemption & 66,7 & 14,2 & 52,5 \\
\hline Provision of housing & 52,5 & 17 & 35,5 \\
\hline Tax-free capital transfer & 43,3 & 13,5 & 29,8 \\
\hline Free access to university studies & 41,1 & 16,3 & 24,8 \\
\hline Possibility of avoiding militaryservice & 45,4 & 23,4 & 22 \\
\hline
\end{tabular}

Although the sample is not enough for sound scientific evidence, some points are remarkable and gain more interest when combined with the extra comments we received. We will discuss these comments along with the results of 30 indepth interviews with high-ranked officials of the Greek Ministry of Foreign Affairs and Greeks whose permanent residence is outside Greece. Obviously, the rise of unemployment and the corruption of the Greek state are the most important reasons that people are migrating, while finding a job and less bureaucracy are the most motivating factors to come back. Real life, however, is much more complex. The main observation of the interviews is the vast diversity of the cases. Migrant behavior is determined by an almost endless variety of factors that even migrants themselves cannot fully express. Such factors are the reason to leave (emotional-financial), the pressure for leaving (voluntary or forced), the opinion of the family (indifferent, supportive or negative), the country of destination, the existence or absence of Greek communities, the personal ability to adapt, the opinion about the elected government (positive or negative), age, gender, city of origin, education level, ambition, greed, momentum of leaving, determination, courage, physical condition, safety, criminality, lack of meritocracy and many others. The existence of so many different factors makes it difficult or even impossible to classify the different cases. Thus, only a few general observations can be made.

1. Migrating is very easy, especially for the young and the well-educated, because of the enhanced possibilities to find and secure a suitable job abroad even before leaving the country or to keep in touch with friends and family through the internet.

2. When there is a point of reference in the city of arrival, such as family members, good job or strong community, the possibility of returning is minimal.

3. There seems to be a tiny time gap between the moment of leaving and the final decision that the one-way ticket is enough. The possibility to return shrinks every time a new target is achieved: community adaptation, job, promotion, love affair, marriage, children, and wealth.

4. Raising children puts parents before the dilemma of the final destination. It seems that in most cases, the opinion prevails to stay abroad, more or less with the same arguments that forced the parents to migrate.

5. Marriage with a non-Greek person, either local or migrant, is the point of no return.

6. The fact that Greece is a top tourist destination has a negative effect. One of the most common intuitive reactions of Greek migrants is, "Why should I return? The ideal is to work abroad in the winter and to enjoy holidays in the Greek summer".

7. The repatriation of Greeks is totally absent from the public, press and political agenda in Greece. There are no repatriation motives for Greeks, let alone a comprehensive policy. The term "repatriation motives" refers exclusively to foreign migrants who think to return to their countries of origin.

8. Horizontal measures are not effective because each case is different. The only solution could be the establishment of a flexible service with the financial means and the authority to negotiate every case separately to offer personally adjusted bundles of motives. Considering the adaptation capacity of the Greek state, this will be the first priority after the establishment of a Greek tax office in Mars.

Migrants and officials agree that we cannot expect positive changes in the near future. Some 2,500 years ago, the ancient city-state of Athens was facing a serious external threat, but the Members of Parliament, bored as they were, were paying no attention to the speakers on the subject. Disturbed by their lack of interest, the famous rhetor Demosthenes asked them to be quiet for just two minutes, as he started recounting the following story:

"A traveler had rented a donkey to carry a cargo and went along with the donkey's owner to his destination. When they made a small stop because of the scorching sun, the traveler and the owner of the donkey argued about which of the two had the legal right to sit in the shade of the animal." 
At this point, Demosthenes interrupted the narrative and descended from the step. The Athenians started shouting and complaining that they wanted to hear until the end of the story. He returned and said to them, "Shame onall of you. You are interested in the shadow of a donkey but not in the danger that your city faces". Similarly, public and political dialogue in modern Greece focuses on trivial issues (such as whether it is right for the Prime Minister to be hosted by tycoons or whether the Minister of Health is allowed to smoke) and totally ignores issues that will determine the survival of the country.

\section{Conclusion: Living without "this"}

The reasons why people migrate are very complex, and this makes the formation of a repatriation policy very difficult. Because of the existence of well-established Greek communities throughout the world, the participation of Greece in the EU and almost every important institution of the Western world and the enhanced possibilities of seeking and applying for jobs online, it is extremely easy for Greeks, and especially young scientists, to seek a better future outside Greece. When they decide to do so, bridges are burned, and even drastically and costly measures are not enough to persuade them to return. The only hope for a change may be hidden in the contradiction that the majority expresses: on the one hand, they claim that they have decided to stay abroad forever, but on the other hand, they state that they miss Greece very much. The Greek administration seems totally unable to understand and take advantage of this last hope. The country needs a new start, but the elite of the new generation that could bring upon a revolution abandoned ship and soughta better future anywhere but Greece. In 480 BC, King Leonidas, with only 300 Spartans, terrified the 300,000-strong Persian army that invaded Greece by slaughtering20,000 of them. The glorious sacrifice of Leonidas and his men played a strategic role in the final victory and the survival of the Western civilization. The ancient Spartans had only two options when facing the countless hordes of Persians who wanted to subdue Europe: "Either with this or on this"- Come back home either victorious with your shield or dead on your shield. Laying down the shield was the ultimate act of disgrace for a warrior in the eyes of his mother or wife. Today's Greek generation still enjoys the outcomes of the battle of Thermopylae, but it has forgotten the shields.

\section{References}

Banulescu-Bodgan, N., \&Fratzke, S., (2015). Europe's migration crisis in context: Why now and what next? Migration Policy Institute. [Online] Available: http://www.migrationpolicy.org/article/europe's-migration-crisis-contextwhy-now-and-what-next (July 1, 2019)

Economou, C., Kaitelidou, D., Kentikelenis, A., Sissouras, A., \&Maresso, A. (2015). The Impact of the financial crisis on the Health System and Health in Greece. Brussels: WHO, European Observatory on Health Systems and Policies).

European Union, (2016). In-Depth Analysis. Greece's Financial Assistance Program. Brussels: Directorate General for Internal Policies, Economic Governance Support Unit. [Online] Available: http://www.europarl.europa.eu/cmsdata/120262/Study\%20-\%20Greece-

Regional\%20policy\%20and\%20economic\%20and\%20social\%20situation.pdf (July 1, 2019)

Eurostat, (2015). 17 October: International Day for the Eradication of Poverty. Brussels: Eurostat News Release 181, Kappa research (2015). Poll on Religious Matters. Athens: To Vima.

Kapur, D. (2014). Political effects of international migration. Annual Review of Political Science, 17, 479-502.

Kassimis C. \&Kassimi C. (2004) Greece: A History of Migration. Athens, Migration Policy Institute. [Online] Available: https://www.migrationpolicy.org/article/greece-history-migration (July 1, 2019)

Korma, L. (2004). The historiography of the Greek diaspora and migration in the twentieth century. French School at Athens.

Kougias, K. (2018). Comparing Greece and Portugal: Common employment trajectories but divergent outcomes? Economic and Industrial Democracy Manuscript.

Labrianidis L. (2014). Outward migration from Greece during the crisis. London: London School of Economic's Hellenic Observatory.

Labrianidis, L. \&Pratsinakis M. (2016). Greece's new emigration at times of crisis. GreeSE Paper no. 99, Hellenic Observatory on Greece and Southeast Europe, LSE.

Petmesidou, M. \&Guillén, A. (2015). Economic crisis and austerity in Southern Europe: Threat or opportunity for a sustainable welfare state? European Social Observatory, Research Paper 18.

Petmesidou, M., Papanastasiou, S., Pempetzoglou, M., Papatheodorou, C. \& Polyzoidis, P. (2015). Health and LongTerm Care in Greece. Athens: Observation for Economic and Social Evolution, INE GSEE.

Mousourou L. M. (1991). Migration and migration policy in Greece and in Europe. Athens: Gutenberg. 
OECD (2015a), Measuring National Well-Being: International Comparisons; Office for National Statistics. [Online] Available:

https://www.ons.gov.uk/peoplepopulationandcommunity/wellbeing/articles/measuringnationalwellbeing/ (July 1, 2019)

Pew Research Center, 2017 The Future of World Religions: Population Growth Projections, 2010-2050. why Muslims are the world's fastest growing religion group. [Online] Available: http://www.pewresearch.org/facttank/2017/04/06/why-muslims-are-the-worlds-fastest-growing-religious-group/ (July 1, 2019)

Rummel, R. J. (1997). Statistics of Turkey's democide estimates, calculations, and sources, Statistics of Democide.

Thegreekzcom.com (2006). Poll: Disappointment and anger against the government. [Online] Available: www.thegreekz.com/forum/showthread.php?736854 (July 1, 2019)

Theodoropoulos, D., Kyridis, A., Zagkos, C. \&Konstantinidou, Z. (2014). "Brain Drain" Phenomenon in Greece: Young Greek scientists on their Way to Immigration, in an era of "crisis". Attitudes, Opinions and Beliefs towards the Prospect of Migration. Journal of Education and Human Development 3(4), 2334-2978.

Trading Economics (2019). Greece Unemployment Rate. [Online] Available: https://tradingeconomics.com/greece/unemployment-rate (July 1, 2019)

Triandafyllidou S. \&Mantanika, S. 2016). Migration in Greece: Recent Developments OECD Network of International Migration Experts [Online] Available: https://www.eliamep.gr/wp-content/uploads/2014/10/2016.pdf (July 1, 2019)

European Commission, (2016): Greece: Response to the Refugee Crisis. Echo Factsheet, Humanitarian aid and civil protection [Online] Available: http://ec.europa.eu/echo/files/aid/countries/factsheets/greece_en.pdf(July 1, 2019)

Tsouvelas, G. Konstantakopoulos, G., Vakirtzis, A., Giotakos, O., Papaslanis, T., \&Kontaxakis, V. (2014). Criminality in Greece during the years of financial crisis. Psychiatriki, 29(1), 19-24.

UN (2017). Population Division, World Population Prospects, 2017. [Online] Available: https://population.un.org/wpp/DataQuery/ (July 1, 2019)

United Nations High Commissioner for Refugees (2015), Number of Refugee Arrivals in Greece [Online] Available: http://www.unhcr.org/news/latest/2015/8/55d32dcf6/numbers-refugee-arrivals-greece-increasedramatically.html (July 1, 2019)

Wilford, J. N. (2007). Languages die, but not their last words. The New York Times.

World Economic Outlook Database, April 2019, International Monetary Fund. Database updated in April 2019 (July 1, 2019)

World Population Clock (2019). Worldometers [Online] Available: www.worldometers.info (July 1, 2019) 